\title{
RI薬品自動発注の試み
}

\section{Trial of Automatic Send an Order for the Radiopharmaceutical}

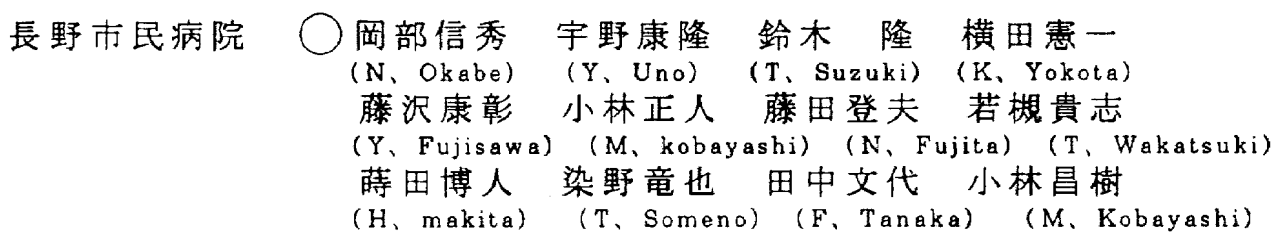

\section{(目的)}

第 52 回総会において R I 検查予約 ・放射性医薬品管理業務の自動化、省力化 について報告した。

今回われわれは、さらにシステムを向上させ業務の効率化を図るために、R I 薬品の 自動発注を試み、基礎的事項を検討したので報告する。

\section{(必須事項)}

R I 薬品自動発注を行うにあたり、必須事項として、病院情報の秘密を

保持し、RI薬品の発注の有無の確認ができなければならないと考えました。

(概要)

1、R I 薬品自動発注起動端末から、定期時刻、現在は 15 時 45 分にRADONサーバへ

R I 薬品発注管理データを検索しにいきます。

2、RI 薬品発注管理データは、テキストファイルとして、RI薬品発注端末に保存されます。

3、R I 薬品メーカーが、ダイヤルアップ機能によって病院側のR I 薬品発注端末に

アクセスします。（現在 16 時前後にアクセスします。）

ここでメーカー側からは、I D とパスワードを

入カしてもらうようになっており、

セキュリテーに関しては、R I 薬品発注

管理データしか参照できないよう限定

しています。

4、メーカー側がR I 楽品発注

管理データを参照します。

5、受付者氏名を入力してもらいます。

6、R I 薬品発注管理表をメーカー側

端末に保存し、病院側にプリント出カし、 保存します。

7、プリント出力された R I 萫品発注

管理表を確認します。

ここで、必須事項で述べたように

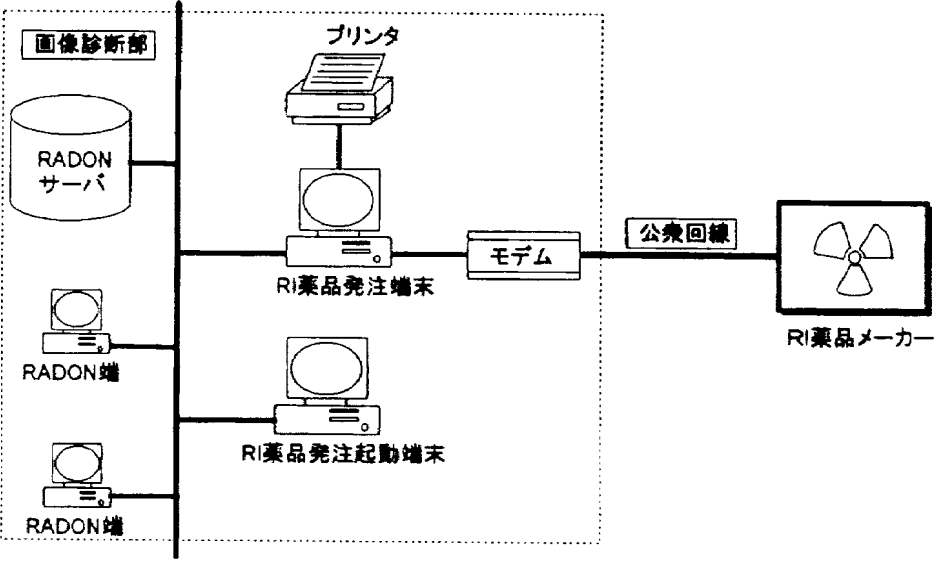

発注薬品に間違いがないか確認することができます。

(結果)

放射線情報システム（R I S ）で、以前より使用していた R I 薬品発注管理データを もとに、病院情報の秘密を保持し、パソコンと W i n d o w s N T 使用することで、

R I 薬品自動発注を安価に確実におこなえた。

(考察)

1、他病院の情報システムにおいても、ファイル形式等を同一にすることにより、 接続が可能な発展性を有していると考える。

2、検定日が祝日、祭日になってしまう場合、現在は直接手で入力することで

変更していますが、検定日の変更カレンダーを取り入れることにより、

さらに使いやすくなると考えます。

3、公衆回線と病院端末の接続について、今後慎重に険討していく必要があると考えます。 